\title{
Remunerations and Gender: The Case of the Polish Government Administration
}

\author{
Ewa Lisowska \\ Institute of International Management and Marketing of the Warsaw School of Economics, Poland
}

Copyright $@ 2015$ Horizon Research Publishing All rights reserved.

\begin{abstract}
The purpose of the paper is to analyse statistical data concerning the gap between the remunerations of men and women in Poland. It also presents the situation in the Polish government administration based on the results of the survey carried out at the turn of 2011 and 2012. Especially the paper discusses the reasons of unequal remunerations identified in the literature on the subject, and gives the answer to the question if the human capital theory explains gender pay gap. In the paper it is presented available data as well as the empirical results on gender pay gap. The main conclusions are as following: (1) Women earn less than men irrespectively of the economy sector, profession, education, age, or size of the organisation; (2) The results of the survey indicate that the situation in the government administration in respect of the pay gap is slightly better than the average in Poland; (3) The human capital theory does not explain gender pay gap because it does not take into account that the choice of a woman is not truly free, as it is restricted by social habits and norms as well as stereotypes.
\end{abstract}

Keywords Gender Pay Gap, Government Administration, Human Capital Theory, Poland, Stereotypes

\section{Introduction}

The principle of equal pay for the same work or work of the same value was first introduced into the European Community primary legislation already in 1957 (Article 119 of the Rome Treaty). As a result of the precedent judgment of the European Court of Justice of 8 April 1976 (case Defrenne II No 43/75) it became clear that Article 119 of the Rome Treaty directly refers to the law of each Member State, as the principle of equal pay for men and women is the foundation of the European Community (see [41:24-25]). Subsequent Treaties, i.e. the Treaty of Amsterdam and the Treaty of Lisbon, also provide for provisions on equal pay for women and men (Article 141 of the Treaty of Amsterdam and Article 225 of the Treaty on the Functioning of the European Union - the Treaty of Lisbon). The secondary legislation stipulates similar provisions, which are comprised in Directive
75/117/EEC and Directive 2006/54/EC.

According to the European Parliament's Report of May 2012 [29], legal regulations applied so far concerning the implementation of the principle of equal opportunities and the principle of equal treatment of men and women in respect of employment and work, as well as the actions taken were not conducive to equality in the area of remunerations: women earn on average less than men whereas it can only partially be explained by factors related to qualifications, working conditions and time involved in work.

In above mentioned report, the European Parliament opts for undertaking strong measures enforcing observance of the law (including, in particular, the provisions of Directive $2006 / 54 / E C)$. It is proposed to introduce obligatory audit of the remuneration system and sanctions for employers who do not observe the principle of equal pay for work of equal value, to oblige the employers to monitor the remunerations in respect of gender and to carry out a transparent remuneration policy, as well as to value work according to qualifications, psychological or physical requirements, interpersonal skills, the level of responsibility for human and material resources [29:7-10]. The governments of the Member States should first of all eliminate the gender pay gaps in government and public institutions, as well as enterprises with the participation of the State Treasury and listed companies, and thus serve as a good example for the private sector.

The purpose of the article is to analyse statistical data concerning the gap between the remunerations of men and women in Poland. In the paper it is presented available data as well as the empirical results on gender pay gap in the institutions of the central administration in Poland where working people, mainly women, are high educated. It discusses the reasons of unequal remunerations identified in the literature on the subject.

\section{Reasons behind the Pay Gap: Literature Review}

Analyses carried out in Poland by Domański [10, 11], Jacukowicz [18], Goraus and Tyrowicz [14], Słoczyński [35] 
and Zajkowska $[43,44]$ clearly show that pay discrimination of women is a significant factor influencing the average gender pay gap. According to Becker's theory $[3,4]$ the discrimination is caused by the traditional perception of the social roles of men and women in a society as well as by women's acceptance of lower pay rates because they have less negotiation power on the labour market.

From the macroeconomic point of view (economy as a whole), it can be stated that the reasons for the differences in the average pay of men and women (based on: Lisowska [20:144-145]; Renzetti and Curran [28:329-340]; Sarata [33:269]) are:

1) Professional segregation - a phenomenon that consists in excessive concentration of one gender in particular professions, sectors of the economy and in some positions; usually women are overrepresented in low-paid professions (such as office employees, primary and secondary school teachers) while men are overrepresented in well-paid professions (e.g. miners, other qualified workers, foremen);

2) Very low share of women in the highest, best-paid managerial positions, especially in large companies (e.g. banks);

3) Stereotypes concerning the perception and valuation of women's qualifications as worse than the skills and qualifications of men, i.e. the androcentric labour market model;

4) Absence of national mechanisms that would balance the negative impact of cultural factors, promote partnership in families and control the observance of the principle of equal treatment of men and women on the labour market and in the society.

If we look at the pay gap from the microeconomic perspective, i.e. the perspective of the jobs (enterprises), we can see that a woman usually starts from a lower level of the salary network, she earns less than her male predecessor in the same position and is promoted at a much slower pace (see Reskin and Hartman [30]; Reskin [31]; Kay and Hagan [19]; Bellas and Coventry [6]; Heilman and Eagly [16]). That is because the flexibility and value of women's work is regarded as worse than the flexibility and value of men's work, and descriptions of positions are incomplete and very general, they do not include such skills as, for example, responsibility and care for others, manual dexterity, good self-management in time, interpersonal communication, intuition - the elements which are the women's advantages.

There is common agreement that "male work" is related to higher income than "female work", while there is no common agreement about the answer to the question what are the reasons of such an attitude. Employers, politicians and economists usually think that it is the result of free choice: people have a free choice of how much they would invest in their education, qualifications and future profession (see Renzetti and Curran [28]; Begg, Fischer and Dornbusch [5]). Women choose professions that make it easier for them to combine family and professional duties. Women identify mainly with their home and family, so they look for a job that does not need too much personal and time involvement, so their financial profits from work are respectively smaller. Such explanation of the reasons for professional segregation and lower salaries of women is enshrined in the human capital theory (see Renzetti and Curran [28: 330]). It says that the pay gap results from differences in work efficiency; better-educated employees are more efficient and consequently they earn more (see Begg, Fischer and Dornbusch [5:334]). Employers in turn prefer those employees who are flexible and do not generate additional costs.

Theory of human capital is used to explain differences in men's and women's wages since 1960s. by e.g. Mincer and Polachek [25]; Polachek [26]; England [12]; Becker [3]; Schultz [34]; Blau and Kahn [7]; Waldfogel [40]; Altonji and Blank [1]; Polachek and Xiang [27]. The results of the analyses have showed that productivity characteristics explain only part of the gender pay gap (no more than $30 \%$ ). This conclusion has been confirmed by the results of research conducting in Poland by Grajek [15]; Goraus and Tyrowicz [14]; Magda and Potoczna [24]; Słoczyński [35]; Zajkowska [43].

The weakness of the human capital theory is that it does not take into account the fact that the choice of a woman is not truly free, as it is restricted by social habits, norms and stereotypes. As Renzetti and Curran [28:330] stated, while it is true that mainly women perform duties related to childcare and running a household, there are doubts about whether it is their free choice or maybe a necessity imposed by the culture and unsuitable government policy concerning childcare solutions. Moreover, the free choice of women in respect of professions or works untypical of their gender, and therefore better paid, is disturbed by the attitudes of officials or employers who stick to stereotypes. A common argument raised by employers in the discussion on the restriction of women's access to employment is that women had not worked in a given sector, profession or in a given position in the past. As pointed out by Reuben et al. [32] and Wolfers [42], stereotypes may undervalue competences of women and overvalue competences of men. Women find it difficult to overcome sticky floor and glass ceiling phenomenon (see e.g. Lisowska [22]; Zwiech [45]; Arulampalam et al. [2]). Therefore, less often they are able to get managerial position.

On the basis of the review of theories explaining pay gaps, they can be divided into three groups: neoclassical theories (including the human capital theory, Becker's theory of discrimination), institutional theories and theories of segmentation on the labour market (including the theory of the dual labour market, theory of statistical discrimination) and the theory of gender economics (see Cichomski [8:342-345]). The latter explains the lower remunerations of women with social norms: the subordinate position of women in the society and the androcentric labour market.

The Report of the European Parliament [29] emphasises that stereotypes and the perception of men and women in the 
light of their traditional roles are the main reasons behind the gender pay gap. It also indicates that "a labour market free of stereotypes could increase not just women's income, but also Member States' gross domestic product (...) [and] if female participation in the labour market were to rise to $70 \%$, matching the male rate, this would have a highly beneficial economic impact (between $4 \%$ and $8 \%$ ) on EU GDP"
[29:17-19]. From this point of view it is very important to oblige (or encourage) employers to monitor / audit remunerations in the workplace and make the remuneration policy free from gender discrimination. The example should get out of the government administration and institution, but that does not happen, which will be discussed below.

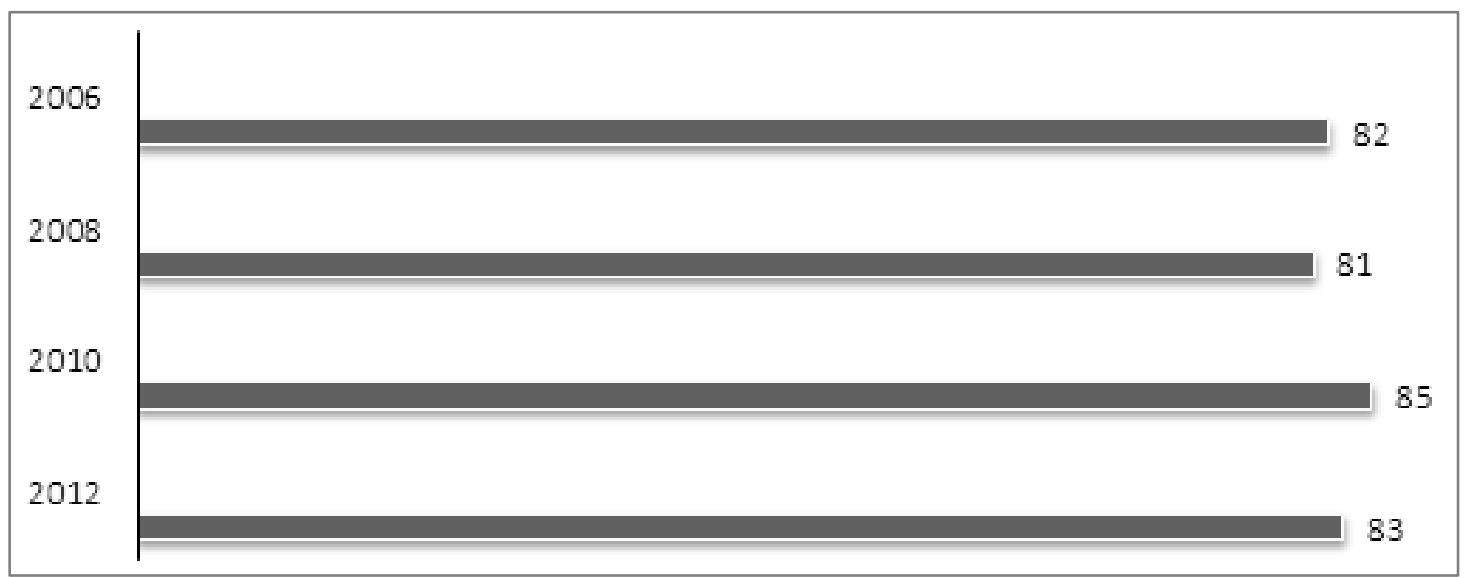

Source: Own calculations based on CSO data from the study on remunerations carried out in 2006, 2008, 2010 and 2012 [36, 37, 38, 39].

Figure 1. Ratio of average women's remunerations to men's remunerations in Poland, total for 2006, 2008, 2010 and 2012 (\%)

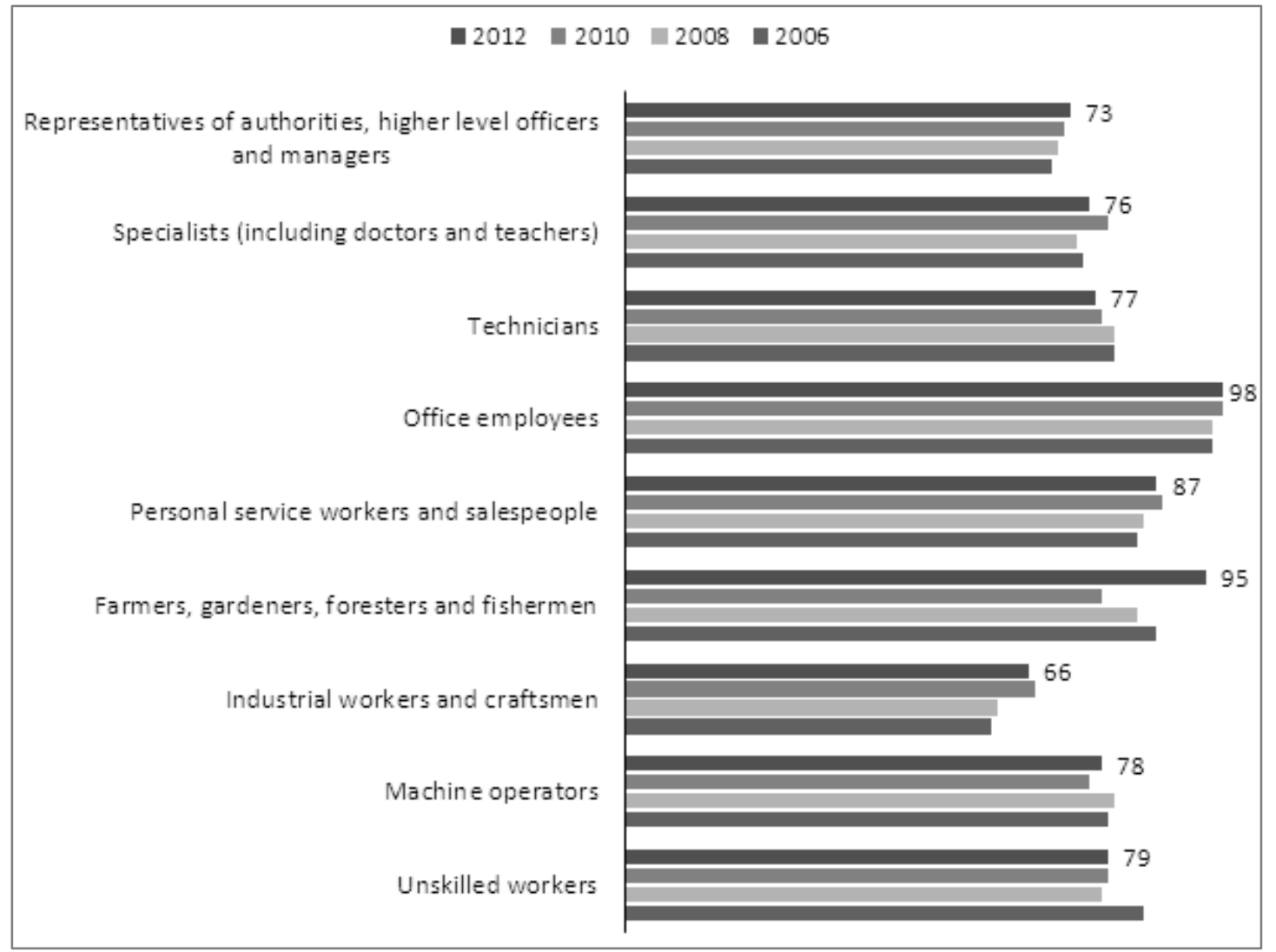

Source: As for Figure 2.

Figure 2. Ratio of average women's remunerations to men's remunerations in Poland according to professional groups in 2006, 2008 , 2010 and 2012 (\%) 


\section{Gender Pay Gap According to Statistical Data}

The disproportion in the remunerations of men and women occurs in all the European Union states, including those with a long tradition of introducing equal treatment solutions into legislation and social practice, such as Sweden, the Netherlands, Finland. The scale of the disproportions in 2012 was between $2.5 \%$ in Slovenia and 30.0\% in Estonia, while the average gender pay gap in the EU-28 was $16.4 \%$ to women' disadvantage, which means that the value of women's pay was lower by this percentage ${ }^{1}$.

Poland is among those European Union countries where the gender pay gap based of hourly rates is one of the lowest. However, the analysis of monthly average gross salary of women and men reveals that there are the significant differences. Data of the Central Statistical Office (CSO) ${ }^{2}$ for 2006, 2008, 2010 and 2012 presented in Figure 1 show that the average gross salary for women constituted, in those years, $82 \%, 81 \%, 85 \%$ and $83 \%$ of average men's gross salary, respectively. If we assume the women's pay as the basis, men earned on average $22 \%$ more than women in 2006 , $23 \%$ more in $2008,18 \%$ more in 2010 and $20 \%$ more in 2012 . The data indicate that in the years 2006-2012 the gender pay gap was above the twenty percentage on average.

Women earn less than men irrespectively of the economy sector, profession, education, age, or size of the organisation. In 2012, according to the CSO data, monthly average gross salary in the public sector was $9 \%$ higher than in the private sector. In the public sector men earned $25 \%$ more than women, in the private sector $-23 \%$ more. The ratio of the average women's pay to the men's pay in the public sector was at the level of $80 \%$, and in the private sector it was $81 \%$.

The largest average remuneration gaps are found in the group of industrial workers and in the group of managers and higher level officers (Figure 2). In 2012, women in these groups earned $66 \%$ and $73 \%$ of men's earnings, respectively. It is positive that in the years 2006-2012, the pay gap in both these group was reduced, whereas the reduction was greater for industry workers than for managers. According to the data for 2012, a relatively smaller pay gap was found in the group of office employees: women earned almost as much as men; in the group of farmers as well as in the group of personal service workers and salespeople: women earned $95 \%$ and $87 \%$ of men's earnings, respectively.

There is no direct relation such as, for example, the higher the share of women employed in a given profession, the smaller the disproportion in remunerations. It proves that the remuneration gap is the smallest in typically men's professions which women have entered only recently. For example, in the group of IT specialists women account for $16 \%$ and they earn $90 \%$ of what men earn. According to Jacukowicz [18:103] relatively the highest disproportion is reported, for example, for mathematicians and statisticians, where women constitute as much as $78 \%$ and earn $48 \%$ of what men earn; in areas where fixed remuneration rules are applied, such as in primary and secondary education, there are no considerable pay gaps, while in areas with diverse didactic posts and functions and pay ranges, for example in higher education, pay differentiation is more evident.

The disproportion between men's and women's pay is particularly evident if analysed it according to the education level (Figure 3). The gap is the largest in the case of basic vocational education: women earn $69 \%$ of what men earn, which proves that male qualified workers receive better pays than female qualified workers. The situation is similar for people with only primary education. It is noticeable that there is a relatively large span of average remunerations of people with higher education, which according to Słoczyński [35:182] does not necessarily result from the fact that professions typical for women requiring such education are generally worse paid than men's professions but from the fact that men hold highest level managerial posts in large enterprises (e.g. banks) and positions of specialists valued the highest by the market definitely more frequently than women.

Analyses carried out by Domański [11:255] between 1982 and 2006 indicate that starting from the beginning of the 1990 s, relatively more women received higher education, which was the result of, among others, the development of private schools and easier access to higher education. Women get a higher rate of return from education 3 than men, especially in the public sector (see Litwiński, Sztanderska [23:178]), so it is profitable for women to graduate from universities. International analyses conducted by Słoczyński [35:181] prove that the average better education of women reduces the gender pay gap (it abates the influence of discriminating factors) in countries such as Poland, Australia, Chile, Philippines, Ireland, Russia, and Uruguay.

In respect of age, relatively the greatest differences in average salaries between men and women are in the 35-44 age group: women earn $78 \%$ of what men earn; the smallest differences are in the 55+ age group, and among the youngest employees: up to 24 years old (Figure 4 ).

3 The rate of return on education is measured by the function of salaries developed by J. Mincer in 1974. Calculations of earnings take into account the number of years of education of a given person and his/her professional experience measured in years of work. The calculations show that people with higher education receive a kind of "bonus" as compared to people with primary education: each education year increases earnings by a certain percentage. This bonus is called rate of return [23:175-176].
1The data concern the unadjusted Gender Pay Gap (GPG), which represents the difference between average gross hourly earnings of male paid employees and of female paid employees as a percentage of average gross hourly earnings of male paid employees at companies employing 10 people and more according to NACE Rev. 2 (except public administration, defense and compulsory social security), http://epp.eurostat.ec.europa.eu/.

In its representative studies on remunerations carried out every two years, the CSO includes national economy entities employing at least 10 people. The data refer to full-time and part-time employees who worked throughou the entire October. Information on earnings are presented as arithmetic means of salaries. The methodology is broadly discussed in [39:10-15]. 


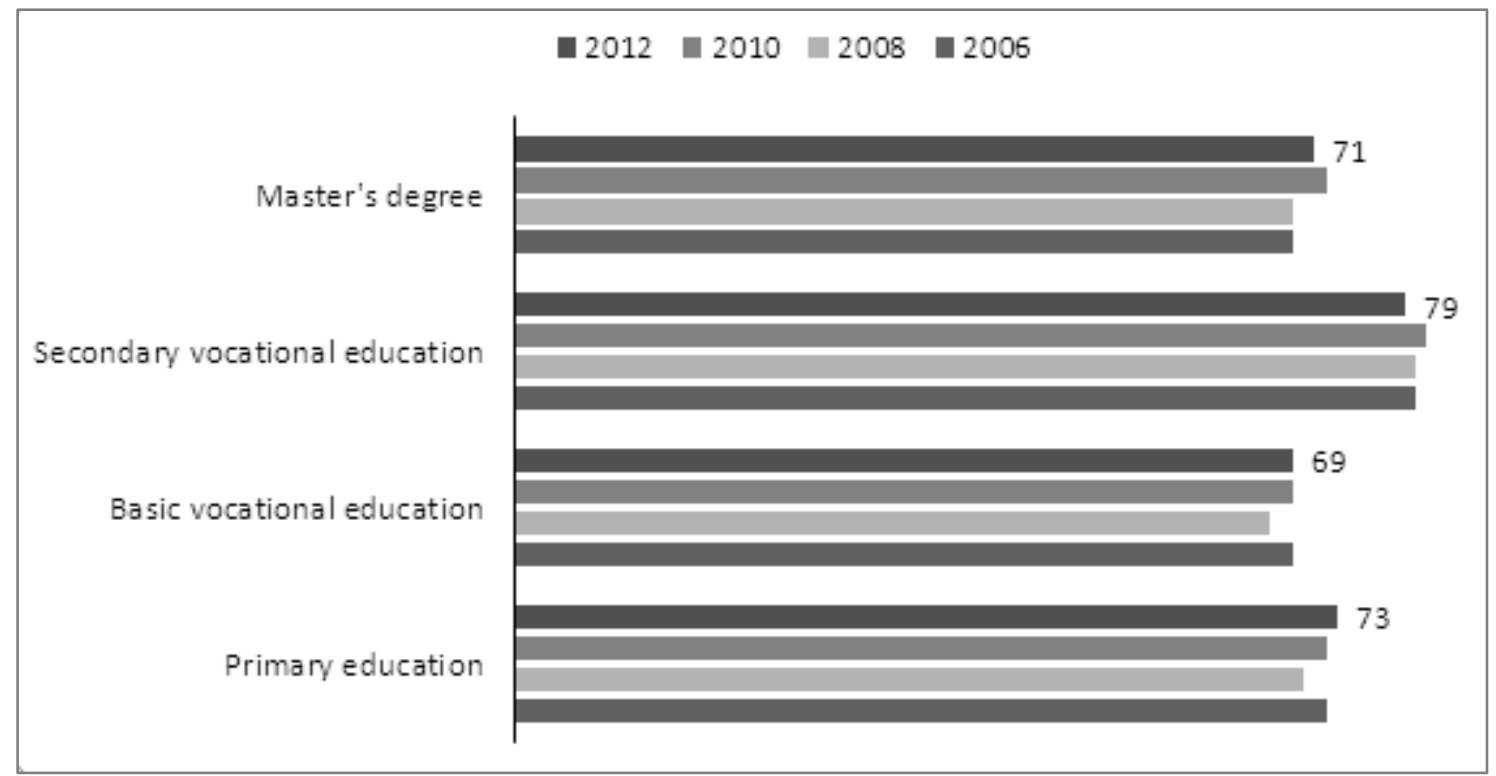

Source: As for Figure 2.

Figure 3. Ratio of average women's remunerations to men's remunerations in Poland according to the education level in 2006, 2008, 2010 and 2012 (\%)

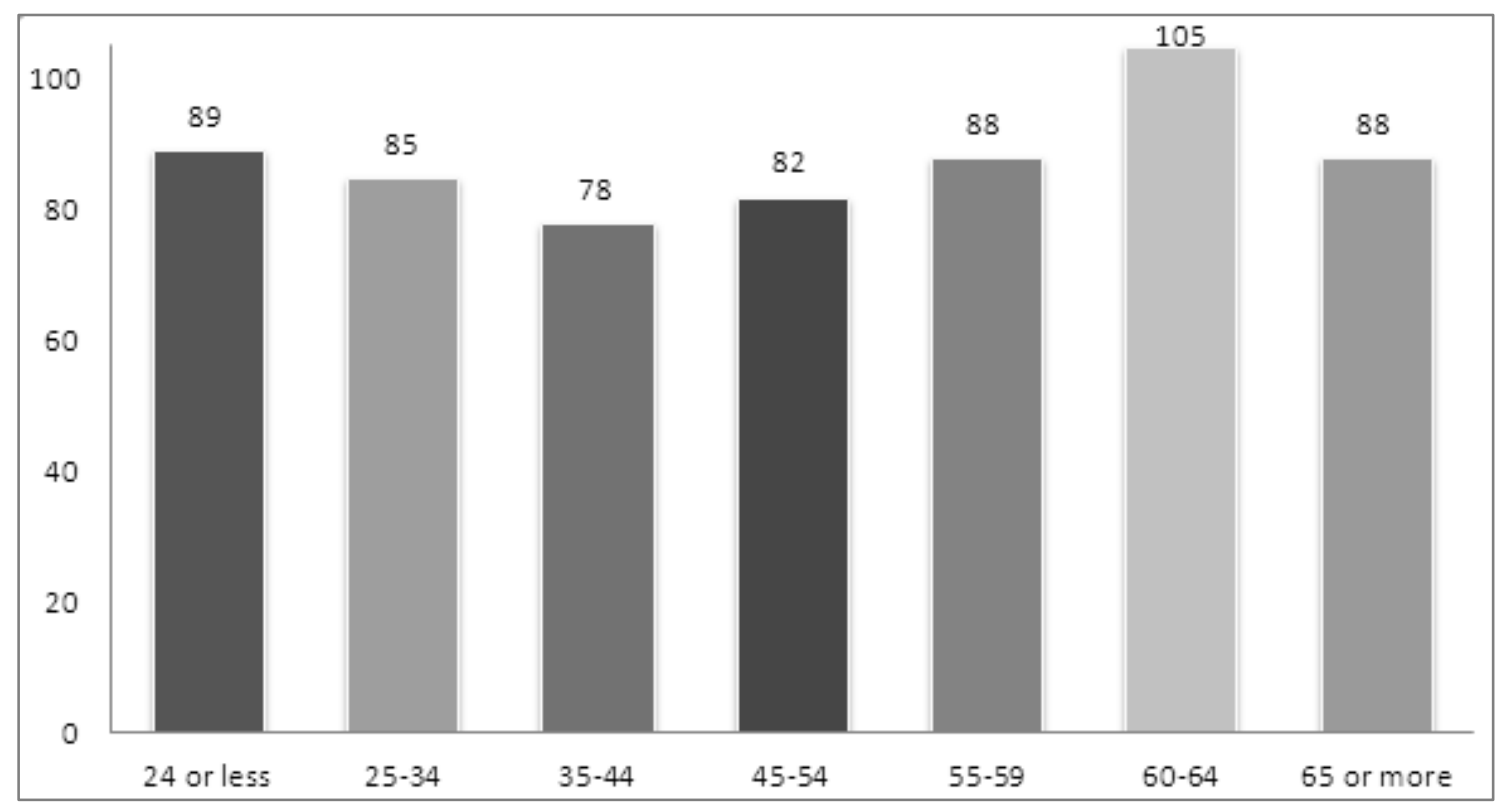

Source: Own calculations based on CSO data from the studies on remunerations in 2012 [39:64].

Figure 4. Ratio of average women's remunerations to men's remunerations according to age in Poland, total in 2012 (\%)

While at the beginning of a career the gender pay gap is therefore inconsiderable, similarly to the pre-pension time, average remunerations during the period when women have children and career breaks connected with caring for children are highly diversified in terms of gender. American studies by Hewlett and Luce [17] indicate that although women have short career breaks (2.2 years on average), it results in "financial discrimination" - women lose from $18 \%$ to $37 \%$ of their earning ability depending on the time span for which they put their career on hold (the longer the break, the bigger the financial loss). Because of the care functions performed by women who want to continue work after giving birth, they often start working part-time or reduce the number of working hours, they are not promoted and do not take professional challenges, because they have to take care of family duties. It is not the case for men who have children, which causes the pay gaps to women's disadvantage in the discussed age groups.

The size of the organisation also differentiates remunerations according to gender: entities with up to 100 employees have more equalised remunerations, while the largest disproportions occur in entities employing 2,000 people or more (Figure 5). 


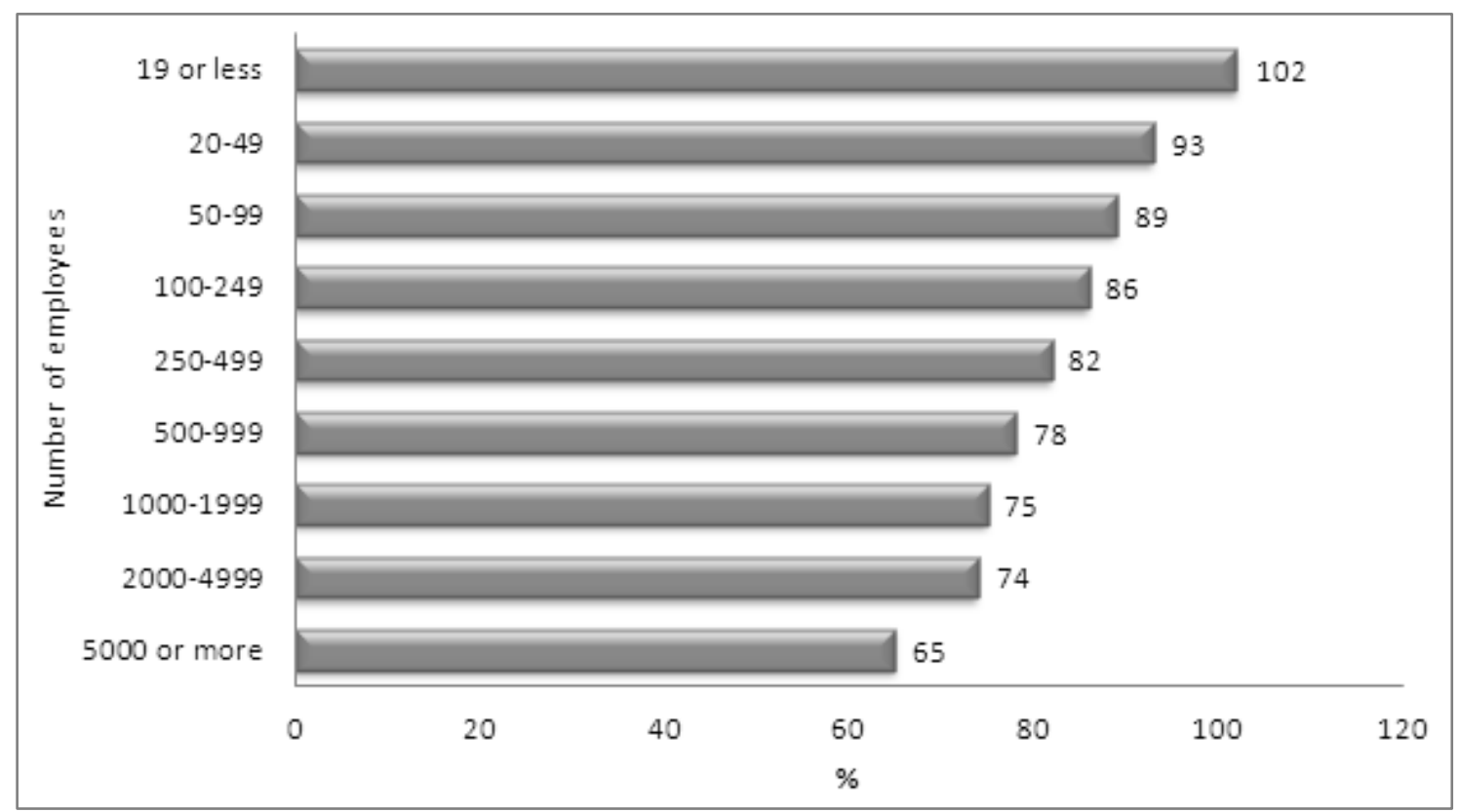

Source: As for Figure 5, p. 65.

Figure 5. Ratio of average women's remuneration to men's remuneration according to the size of the organisation in Poland, total in 2012 (\%)

Summarized, women on average earn less than men. Female-dominated occupations although require better qualifications, offer smaller remunerations. For example in 2012 a nurse on average had lower gross wage than a driver, electrician and locksmith. School teacher earned on average less than electrician and pitman [39:75-81]. This phenomenon occurs over all sectors, companies and individual characteristics of workers. What differs is only size of the disparity. Although over time women tend to be better educated and gain more labour market experience, the gender pay gap does not close even in the public institutions.

\section{Survey Results4: Gender Pay Gap in the Polish Government Administration}

The monitoring of salaries as a practice providing knowledge on real salaries of men and women and in particular positions was applied only in three out of the seventeen Polish government institutions covered by the study. 5

4 The survey was conducted by the author of this article and Warsaw School of Economics at the turn of 2011 and 2012 within the project "Equal Treatment as a Standard for Good Governance", financed by the Social European Fund. Two questionnaires were used: one was for a HR department and the other for the employees of the 16 ministries and the Chancellery of the Prime Minister. It covered all personnel. The employees filled in the questionnaire on-line. The questionnaire was filled in by 3,061 people (1,003 men and 2,058 women) out of the 14.5 thousand people employed at the surveyed government institutions, as at the end of June 2011. The average rate of questionnaires filled in was $21 \%$. The sample was not representative: among the respondents women and the youngest people were overrepresented [21].

5 It is proven by data received from the HR departments concerning the remunerations of men and women in 2010. Since four ministries did not provide data on salaries and another four provided data which are questionable in respect of their correctness (cases where total average salary
The salaries of men and women differed considerably among particular ministries: in 2010 the average monthly salary of men was between PLN 5,114 and 8,193, while the average salary of women was between PLN 4,203 and 7,002. Those employed in the government administration, both men and women, earned more than the average in 2010 for the public sector both in Poland (PLN 4,253 for men and 3,557 for women) and in Mazowieckie Voivodeship (PLN 4,846 for men and 4,085 for women).

The span of the ratio of men's salaries to women's salaries in total was between $82 \%$ and $99 \%$ in the central administration entities under analysis; three of them had greater pay disproportion than the national average, one had the same and five had a smaller gap. Disproportions of salaries in managerial positions were between $83 \%$ and $102 \%$, in administrative positions - between $89 \%$ and $103 \%$, and in lower posts they were relatively the largest - between $55 \%$ and $107 \%$.

The data indicate that the situation in the government administration in respect of the pay gap was slightly better than the average in the public sector in Poland. It is the case particularly for managerial positions, where the salaries of men and women in central authorities were more similar than in the case of the national average for higher officials and managers (women earned $74 \%$ of what men earned while in central administration at least $83 \%$ ).

\subsection{Indirect Remuneration and Gender}

The results of studies conducted in 2006 and 2007 under

is higher an than average salary in managerial positions), the situation in the entire government administration cannot be determined (the average salary for all the institutions under analysis cannot be calculated). The analysis can therefore refer to only nine ministries. 
the "Gender Index" project [13] in enterprises of various sizes prove that providing indirect remuneration (fringe benefits) is a common practice: they were offered by almost all large enterprises and by $85-88 \%$ of small and medium-sized enterprises (see Ciesielska [9:61]). It is also common to provide more benefits to people in managerial positions than to those in lower positions, and companies where people on maternity and childcare leave can receive benefits are exceptional.

It was also the case for the government institutions - there was not even one which would not offer any benefits. Usually more benefits were offered to people in managerial positions than to people in lower positions. Some ministries offered a small number of benefits (e.g. only three to the people in managerial positions and two in the other ones), some offered more: seven ministries offer five or six benefits for managerial positions, eight ministries offer seven to eight benefits and one - nine benefits. A questionnaire directed to HR departments covered 14 potential benefits.

The most common benefits in managerial positions were mobile phones, laptops, parking spaces, slightly less common benefits were co-financing of holidays, USB drives, co-financing of sports and leisure activities, individual courses in foreign languages and company cars. One institution declared a canteen for VIPs and one declared a medical care package. None of the ministries offered benefits such as: medical care package for the employee's family members, employee pension scheme, co-financing of catering in the form of a lunch ticket or a buffet/canteen.

For the rest of employees, holding lower positions, the most commonly declared benefits are co-financing of holidays, a laptop and parking space; while a USB drive, mobile phone and financing sports and leisure were less common. It should be noted that according to declarations included in the surveys of HR departments of the ministries and the Chancellery of the Prime Minister, women receive the same bonuses as men.

People on a maternity leave received some benefits usually co-financing of holidays, co-financing of sports and leisure and laptops, less commonly - mobile phones, USB drives, parking spaces, medical care packages or individual foreign language courses. People on a childcare parental leave (3 years) most commonly received co-financing of holidays and sports and leisure, but rarely laptops, mobile phones, USB drives, parking spaces and individual foreign language courses.

It should be noted that co-financing of day care or kindergartens was only offered to the employees of three ministries, while co-financing of sports and leisure activities was offered to the employees of eleven ministries. Therefore, co-financing of sports and leisure was more common that co-financing of childcare. Studies carried out at enterprises in 2006 [Gender Index 2007] showed that sports and leisure activities were usually attended by men and it can be presumed that it is also the case for the ministries (this aspect was not covered by the government administration survey).

\subsection{Employees' Opinions on the Pay Gap}

Slightly less than a half of the employees of government administration who responded to the survey said that the socio-demographic aspects influence their income (including all the additional benefits, bonuses, prizes), but the difference between the responses of men and women is considerable: more women $(49 \%)$ indicated such influence than men $(47 \%)$. The most commonly indicated features were age and gender $-32 \%$ of men and $36 \%$ of women indicated age, while $13 \%$ of men and $37 \%$ of women indicated gender (the difference is statistically significant). Features such as disability, sexual orientation, nationality or religion were very rarely indicated as features differentiating the amounts of salaries - see Table 1.

Table 1. People employed in the government administration according to gender, age and their answer to the question whether socio-demographic features influence the earnings (\% of "yes" answers)

\begin{tabular}{|c|c|c|c|c|c|c|c|c|c|c|c|}
\hline \multirow{2}{*}{ Analysed features } & \multicolumn{3}{|c|}{ By gender } & \multicolumn{9}{|c|}{ By age } \\
\cline { 2 - 15 } & \multirow{2}{*}{ total } & men & Women & \multicolumn{2}{|c|}{ Up to 34 } & \multicolumn{2}{|c|}{$35-44$} & \multicolumn{2}{|c|}{$45-54$} & \multicolumn{2}{c|}{$55+$} \\
\hline Age & 35 & 32 & 36 & 37 & 36 & 25 & 29 & 27 & 36 & 32 & 48 \\
\hline Gender & 29 & 13 & 37 & 15 & 37 & 17 & 39 & 9 & 38 & 3 & 36 \\
\hline Disability & 3 & 3 & 3 & 3 & 3 & 5 & 3 & 2 & 3 & 2 & 5 \\
\hline Sexual orientation & 2 & 2 & 1 & 2 & 2 & 3 & 1 & 4 & 1 & 1 & 2 \\
\hline Nationality & 1 & 2 & 1 & 1 & 1 & 2 & 1 & 3 & 2 & 2 & 2 \\
\hline Religion & 1 & 2 & 1 & 2 & 1 & 2 & - & 4 & 1 & - & 3 \\
\hline None & 55 & 63 & 51 & 58 & 50 & 68 & 54 & 71 & 51 & 66 & 47 \\
\hline Number of respondents (N=100) & 3061 & 1003 & 2058 & 475 & 937 & 241 & 607 & 130 & 285 & 154 & 228 \\
\hline
\end{tabular}

Source: Own study based on the questionnaire survey within the project "Equal Treatment as a Standard for Good Governance" at the turn of 2011 and 2012 [21]. 
According to more than $1 / 3$ of women both gender and age influence the salaries, especially women aged 45-54 and 55 or more years gave such declaration. Evidently more men indicated age than gender, so in men's opinion (especially the youngest and the oldest ones) that was the main demographic feature determining the salaries. The influence of age can be considered in respect of both the number of years of work for a ministry (the higher the number, the higher the salary), as well as in respect of discrimination of young employees and those aged 55 or more years, as they less frequently participate in training courses, are less frequently promoted and thus their wages do not increase. It cannot be established on the basis of the results to what extent the declared influence of age results from aged discrimination and to what extent it results from seniority.

Although the data presented above illustrate subjective feelings of the employees, they are certainly shaped on the basis of observation of their own situation compared to the situation of their colleagues, as well as on the basis of general atmosphere of creating a workplace free from any forms of discrimination. According to women working in the government administration, the salaries are highly vulnerable to unequal treatment based on gender - this issue received an average ratio of 5.15 on a 1-7 scale, where 1 stands for the smallest risk and 7 for the highest risk. For men, the salaries ranked third with the ratio value of 4.36; in the opinion of men, the area of combining family duties with professional duties is more vulnerable to discrimination (4.52), as well as sexual harassment and mobbing (4.45).

\subsection{Trainings and Raising the Salaries}

The salary policy can also be extended to cover the costs of trainings and raising qualifications by higher education, postgraduate and doctoral studies, as well as granting prizes and raising the salaries of employees who further their education. Analysis of the data concerning the answer to the question whether the ministry covers the costs of employee education proves that it does sometimes (about 2/3 of women and men said so), while $16 \%$ of men and $13 \%$ of women said it always does. People aged $45-54$ and 55 or more years more often than the younger indicated that their employer always covers the costs of education thus facilitating raising qualifications and promotion, whereas men in this age said so slightly more frequently than women (Table 2). It certainly results from their personal experience, i.e. whether they received such financing, on which the respondents based their answers. The general conclusion is that in the government administration older people (mainly men) can count on financing their education by their employer.

Does raising qualifications by the employees of government administration help to receive a financial bonus or a higher salary? Only $12 \%$ of all the respondents answered "yes" to this question (15\% of men and $11 \%$ of women) in respect of a financial bonus and 15\% (16\% of men and 15\% of women) in respect of a raise (Table 3). Men indeed more frequently than women said that raising qualifications had resulted in a financial bonus, especially men aged 35-44 ( $18 \%$ of this age group) and 55 or more years $(15 \%)$. Among women, those aged 45-54 most frequently pointed to receiving a financial bonus, while the youngest and the oldest mentioned it the least frequently. A raise was received on average by more men and women aged 45-54 ( $21 \%$ of men and $9 \%$ of women) and those aged 55 or more years ( $18 \%$ of men and $16 \%$ of women).

Table 2. People employed in Polish government institutions according to gender and age, and their answers to the question whether their employer covers the costs of education $(\%)$

\begin{tabular}{|c|c|c|c|c|c|c|c|c|c|}
\hline \multirow{3}{*}{ Does the institution cover the costs of education? } & \multirow{3}{*}{ Total } & \multicolumn{8}{|c|}{ Age } \\
\hline & & \multicolumn{2}{|c|}{ Up to 34} & \multicolumn{2}{|c|}{$35-44$} & \multicolumn{2}{|c|}{$45-54$} & \multicolumn{2}{|c|}{$55+$} \\
\hline & & men & women & men & women & men & women & men & women \\
\hline Yes, always & 14 & 14 & 12 & 13 & 13 & 22 & 17 & 21 & 15 \\
\hline Yes, sometimes & 73 & 73 & 75 & 70 & 71 & 70 & 74 & 72 & 78 \\
\hline No, never & 12 & 13 & 12 & 17 & 16 & 8 & 9 & 7 & 7 \\
\hline Total $\mathrm{N}=100$ & 3,061 & 475 & 937 & 241 & 607 & 130 & 285 & 154 & 228 \\
\hline
\end{tabular}

Source: As for Table 1. 
Table 3. People employed in ministries according to gender and age and their answer to the question whether raising qualifications helped to receive a financial bonus or pay rise (\%)

\begin{tabular}{|c|c|c|c|c|c|c|c|c|c|c|c|}
\hline \multirow{3}{*}{ It helped to receive: } & \multirow{2}{*}{\multicolumn{3}{|c|}{ Gender }} & \multicolumn{8}{|c|}{ Age } \\
\hline & & & & \multicolumn{2}{|c|}{ Up to 34} & \multicolumn{2}{|c|}{$35-44$} & \multicolumn{2}{|c|}{$45-54$} & \multicolumn{2}{|c|}{$55+$} \\
\hline & Total & men & Women & men & women & men & women & men & women & men & women \\
\hline \multicolumn{12}{|c|}{ A financial bonus } \\
\hline Yes & 12 & 15 & 11 & 14 & 10 & 18 & 10 & 12 & 16 & 15 & 12 \\
\hline No & 82 & 79 & 83 & 80 & 86 & 76 & 85 & 79 & 76 & 77 & 80 \\
\hline \multicolumn{12}{|c|}{ A pay rise } \\
\hline Yes & 15 & 16 & 15 & 14 & 13 & 17 & 15 & 21 & 19 & 18 & 16 \\
\hline No & 79 & 77 & 80 & 80 & 83 & 77 & 80 & 70 & 73 & 74 & 76 \\
\hline Not applicable* & 6 & 7 & 5 & 6 & 4 & 6 & 5 & 9 & 8 & 8 & 8 \\
\hline Total $(\mathrm{N}=100)$ & 2,984 & 975 & 2,009 & 465 & 924 & 234 & 588 & 126 & 277 & 147 & 219 \\
\hline
\end{tabular}

*\% of employees who did not further their education. Source: As for Table 1.

\section{Discussion}

The analysis presented above, which was based on the empirical surveys realized in all ministries in Poland, shows that remunerations are highly vulnerable to unequal treatment not only based on gender, but also on age. The ministries which monitored their wage system and thus had knowledge on the differences in earnings were rare exceptions. The remuneration policy for male and female employees comprises an element of indirect remuneration (fringe benefits) which are offered by each of the central institution, although in various numbers. What is important, men and women received them on an equal basis. The weakness of the indirect remuneration policy was that the benefits were often withdrawn if a woman went on a maternity or childcare leave.

A part of the research was questionnaire survey among the employees. All of them were asked to take part in the survey however only $21 \%$ responded (3,061: 1,003 men and 2,058 women out of the 14.5 thousand employed at the surveyed institutions in 2011). This sample was not representative. Statements of male and female employees prove that a considerable number of them (not the majority though) noticed signs of salary discrimination based on gender and age. The respondents' statements also show that men slightly more frequently than women receive financial bonuses or pay rises as a result of furthering their education. It is recommended to confirm the results in further research based on representative sample of the employees.

Nevertheless, the analysis shows that the European standard of remuneration policy in the Polish government administration has not been fully implemented yet. Obligatory monitoring of salaries in respect of age and gender should be introduced in all the central government institutions. What more, an annual audit of the salaries received by men and women in the same positions should be carried out. It should be also ensured that benefits are not withdrawn for people on maternity and childcare leaves.

\section{Conclusions}

Statistical data as well as the results of empirical surveys conducted in enterprises as well as in the central government institutions in Poland indicate a gender pay gap. Data of the Polish Central Statistical Office regarding differences in average gross remunerations point out that women earn less than men irrespectively of the economy sector, profession, education, age, or size of the organisation. The results of the empirical survey show that the situation in the government administration in respect of the gender pay gap is slightly better than the average in the public sector in Poland.

In Poland there is still little research explaining the reasons for differences in pay between women and men. Previous results have indicated that only part of the gender pay gap can be explained by differences in individuals' characteristics. Women earn less not because they are less educated, and have less work experience or qualification than men but because women's work is culturally valued lower than the work of men, and that women's choices are limited on the labour market by cultural factors. It means that the human capital theory does not explain gender pay gap as it does not take into account that the choice of a woman is not free, and it is restricted by social habits, norms and stereotypes.

It would be interesting to conduct an empirical research on men and women's remunerations in the context of gender stereotypes and the theory of gender economics. 


\section{REFERENCES}

[1] Altonji J.G., Blank R.M., 1999, Race and gender in the labor market, in: O. Ashenfelter, D. Card (eds.), Handbook of Labor Economics, Elsevier, ed. 1, vol. 3, chapter 48, pp. 3143-3259

[2] Arulampalam W. et al., 2007, Is There a Glass Ceiling over Europe? Exploring the Gender Pay Gap across the Wage Distribution, "Industrial and Labor Relations Review", vol. 60(2), pp. 163-186

[3] Becker G., 1985, Human Capital, Effort, and the Sexual Division of Labor, "Journal of Labor Economics", vol. 3(1), pp. S33-58

[4] Becker G., 1990, Ekonomiczna teoria zachowań ludzkich, PWN, Warszawa

[5] Begg D., S. Fischer, R. Dornbusch, 2000, Mikroekonomia, PWE, Warszawa

[6] Bellas M.L., Conventry B.T., 2001, Salesmen, saleswomen, or sales worker? Determinations of the sex composition of sales occupations, "Sociological Forum", vol. 16 (1), pp. 73-98

[7] Blau F.D., Kahn L.M., 1997, Swimming Upstream: Trends in the Gender Wage Differential in the 1980s, "Journal of Labor Economics", vol. 15(1), pp. 1-42

[8] Cichomski B., 2006, Wynagrodzenia kobiet i mężczyzn w latach 1996-2002, in: Krajowy system monitorowania równego traktowania kobiet i mężczyzn, SCHOLAR, Warszawa

[9] Ciesielska M., 2007, Wynagrodzenia kobiet i mężczyzn, in: Gender Index. Monitorowanie równości kobiet i mężczyzn w miejscu pracy, ed. E. Lisowska, EQUAL, UNDP, Warszawa

[10] Domański H., 1992, Zadowolony niewolnik? Studium o nierównościach między mężczyznami i kobietami w Polsce, IFiS PAN, Warszawa

[11] Domański H., 2011, Nierówności płci w latach 1982-2008, in: Gender w społeczeństwie polskim, eds. K. Slany, J. Struzik, K. Wojnicka, NOMOS, Kraków

[12] England P., 1982, The Failure of Human Capital Theory to Explain Occupational Sex Segregation, "The Journal of Human Resources", vol. 17(3); pp. 358-370

[13] Gender Index, 2007, Monitorowanie równości kobiet i mężczyzn w miejscu pracy, red. E. Lisowska, EQUAL, UNDP, Warszawa

[14] Goraus K., Tyrowicz J., 2014, Gender Wage Gap in Poland Can It Be Explained by Differences in Observable Characteristics?, University of Warsaw, Faculty of Economic Science, "Working Paper" No. 11

[15] Grajek M., 2003, Gender Pay Gap in Poland, "Economic Change and Restructuring", vol. 36(1); pp. 23-44

[16] Heilman M.E., Eagly A.H., 2008, Gender Stereotypes Are Alive, Well, and Busy Producing Workplace Discrimination, "Industrial and Organizational Psychology", No. 1, pp. 393-398

[17] Hewlett S.A., Luce C.B., 2005, Off-ramps and on-ramps: keeping talented women on the road to success, "Harvard Business Review", vol. 83(3), pp. 43-54
[18] Jacukowicz Z., 2000, Zróżnicowanie płac w Polsce, w krajach Unii Europejskiej i w USA, IPiSS, Warszawa

[19] Kay F.M., Hagan J., 1995, The persistent glass ceiling: Gendered inequalities in the earnings of lawyers, "The British Journal of Sociology", vol. 46(2), pp. 279-310

[20] Lisowska E., 2010, Równouprawnienie kobiet i mężczyzn w społeczeństwie, Szkoła Główna Handlowa, Warszawa

[21] Lisowska E. (ed.), 2012, Polityka różnorodności w administracji centralnej, Szkoła Główna Handlowa, Warszawa

[22] Lisowska E., 2013, Zasada parytetu płci na stanowiskach kierowniczych, "Ruch Prawniczy, Ekonomiczny i Socjologiczny", vol. 4; pp. 147-161

[23] Litwiński J., Sztanderska U., 2007, Wykształcenie a płace: stopa zwrotu z edukacji, in: Edukacja dla pracy. Report Poland 2007, UNDP, Warszawa

[24] Magda I., Potoczna M, 2014, Does flexible employment pay? European evidence on the wage perspectives of female workers, "NEUJOBS Working Paper" No. 16.3

[25] Mincer J., Polachek S.W., 1974, Family Investments in Human Capital: Earnings of Women, "Journal of Political Economy", vol. 82(2), pp. S76-S108

[26] Polachek S.W., 1981, Occupational Self-Selection: A Human Capital Approach to Sex Differences in Occupational Structure, "The Review of Economics and Statistics", MIT Press, vol. 63(1), pp. 60-69

[27] Polachek S.W., J. Xiang, 2009, The Gender Pay Gap across Countries: A Human Capital Approach, SOE Papers on Multidisciplinary Panel Data Research 227, DIW Berlin

[28] Renzetti C.M., Curran D.J., 2005, Kobiety, mężczyźni i społeczeństwo [Women, men, and society], PWN, Warszawa

[29] Report 2012: Report with recommendations to the Commission on application of the principle of equal pay for male and female workers for equal work or work of equal value (2011/2285(INI), Committee on Women's Rights and Gender Equality, European Parliament, Report A7-0160/2012, http://www.europarl.europa.eu/

[30] Reskin B.F., Hartman H.I. (eds.), 1986, Women's work, men's work: Sex segregation on the job, Washington DC, National Academy Press

[31] Reskin B., 1993, Sex segregation in the workplace, "Annual Review of Sociology", vol. 19, pp. 241-270

[32] Reuben E. at al., 2012, The emergence of male leadership in competitive environments, "Journal of Economic Behavior and Organization", vol. 83, pp. 111-117

[33] Sarata N., 2011, Rynek pracy w Polsce - płeć, obecność, uczestnictwo, in: Gender w społeczeństwie polskim, eds. K. Slany, J. Struzik, K. Wojnicka, NOMOS, Kraków

[34] Schultz T.P., 1995, Investment in Women's Human Capital, University of Chicago Press

[35] Słoczyński T., 2012, Wokół międzynarodowego zróżnicowania międzypłciowej luki płacowej, „Zeszyty Naukowe Kolegium Gospodarki Światowej SGH”, No. 34

[36] Struktura wynagrodzeń według zawodów w październiku 
2006 r. [Structure of wages and salaries by occupations in October 2006], GUS, Warszawa 2007

[37] Struktura wynagrodzeń według zawodów w październiku 2008 r. [Structure of wages and salaries by occupations in October 2008], GUS, Warszawa 2009

[38] Struktura wynagrodzeń według zawodów w październiku 2010 r. [Structure of wages and salaries by occupations in October 2010], GUS, Warszawa 2012

[39] Struktura wynagrodzeń według zawodów w październiku 2012 r.[Structure of wages and salaries by occupations in October 2012], GUS, Warszawa 2014

[40] Waldfogel J., 1998, Understanding the 'Family Gap' in pay for women with children, "Journal of Economic Perspectives", vol. 12(1), pp. 157-170
[41] Wandzel M., 2003, Równe traktowanie mężczyzn i kobiet, Universitas, Kraków

[42] Wolfers J., 2006, Diagnosing discrimination: Stock returns and CEO gender, "Journal of the European Economic Association", vol. 4, pp. 531-541

[43] Zajkowska O., 2013, Gender Pay Gap in Poland. Blinder-Oaxaca Decomposition, "Quantitative Methods in Economics”, vol. XIV, No. 2, pp. 272-278

[44] Zajkowska O., 2014, Wpływ preferencji pracowników na lukę wynagrodzeniową między kobietami a mężczyznami w Polsce, „Studia i Prace WNEiZ”, No. 36; vol. 2, pp. 415-426

[45] Zwiech P., 2011, Rodzaje dyskryminacji na rynku pracy, "Polityka Społeczna", No. 4(445); pp. 17-20 